\title{
Gangguan Tidur pada Lanjut Usia
}

\author{
Sri Sunarti ${ }^{1}$, Helena $^{2}$ \\ ${ }^{1}$ Konsultan Divisi Geriatri Ilmu Penyakit Dalam Fakultas Kedokteran Universitas Brawijaya \\ Malang \\ ${ }^{2}$ Program Pendidikan Dokter Spesialis Ilmu Penyakit Dalam Fakultas Kedokteran Universitas \\ Brawijaya Malang \\ J1. Veteran Malang 65145 Jawa Timur Indonesia \\ Fax.(62) (0341) 564755 \\ Email: sri_sunarti.fk@ub.ac.id;helena.3587@gmail.com
}

\begin{abstract}
ABSTRAK
Sekitar 50\% orang lanjut usia mengalami kesulitan tidur gangguan tidur memberikan pengaruh negatif yang signifikan pada kesehatan fisik dan mental, terutama pada orang lanjut usia. Gangguan tidur pada orangtua dapat bersifat akut atau kronis, dapat disebabkan karena faktor intrinsik atau gangguan tidur primer atau sekunder akibat penyakit lain, gangguan psikologis atau fisik, faktor lingkungan dan efek samping obat. Gangguan tidur dapat mempengaruhi kualitas hidup pada orangtua, menurunkan status imunologi, gangguan hormonal dan endokrinologi, serta penurunan fungsi kognitif. Manajemen untuk gangguan tidur ini meliputi terapi non-farmakologis dan farmakologis. Perubahan perilaku dan modifikasi diet pada beberapa penyebab gangguan tidur terbukti efektif. Intervensi non-farmakologis seperti sleep hygiene dan terapi perilaku kognitif merupakan terapi lini pertama pada berbagai gangguan tidur.
\end{abstract}

Kata Kunci: lanjut usia, gangguan tidur, manajemen

\begin{abstract}
Approximately 50\% of the elderly complain of sleep difficulty. Sleep disorders causes a significant negative effect on mental and physical health, particularly among the elderly. Sleep disorders in older adult may be an acute or chronic process, can be caused by intrinsic factor or primary sleep disorders or secondary result from other disease, psychological or physical disorders, sleep environment and side effect of the drugs. Sleep disorders influence the quality of life in elderly, decrease immune status, hormonal disorder, endocrinology disorder, and decrease of cognitive functions. Management of sleep disorder include nonpharmacologic and pharmacologic therapy. Behavioral changes and diet modification in several sleep diorders are proven effective. Nonpharmacological interventions such as sleep hygiene and cognitive behavioral treatments are the first line treatment in various sleep disorders.
\end{abstract}

Keywords: elderly, sleep disorders, management 


\section{PENDAHULUAN}

Mendapatkan tidur yang adekuat dan mempertahankan irama tidur dan bangun harian yang normal penting untuk mempertahankan kesehatan fisik dan mental yang baik dan menurunkan risiko berbagai penyakit. Gangguan tidur akut menyebabkan gangguan pada fungsi endokrin dan metabolisme glukosa. Gangguan tidur kronik dan gangguan irama harian memberikan beberapa efek negatif jangka panjang pada kesehatan, termasuk peningkatan risiko terjadinya kanker dan resisten terhadap pengobatan dari kanker. Efek negatif dari gangguan tidur juga berpengaruh terhadap fungsi sistem imun. Peningkatan risiko penyakit metabolik, respons imun yang lemah, dan perbaikan jaringan yang tidak adekuat terkait dengan akumulasi defisit kesehatan yang meningkat dan meningkatkan 'frailty' pada orang lanjut usia (lansia) (1).

Tidur juga telah terbukti terlibat dalam plastisitas otak dan konsolidasi terhadap informasi yang baru didapat, sehingga adanya gangguan tidur dapat mengganggu proses belajar dan daya ingat. Selain itu, tidur juga memegang peranan penting dalam memfasilitasi klirens produk metabolik dari metabolisme neuronal, termasuk zat yang paling erat kaitannya dengan terjadinya penyakit Alzheimer, $\beta$-amyloid(1).

Gangguan tidur tersering pada lansia adalah kesulitan untuk mulai tidur (sleep onset problems), kesulitan mempertahankan tidur nyenyak (deep maintenance problem), bangun terlalu pagi (early morning awakening/EMA) (2,3,4). Lebih dari $80 \%$ orang usia lebih dari 65 tahun melaporkan gangguan tidur. Waktu tidur total harian relatif tetap stabil pada lanjut usia yang sehat, pada mereka dengan usia 60 tahun keatas yang memiliki waktu tidur rata-rata 6,5 - 7 jam per hari (1).

Perubahan pola tidur selama proses penuaan berhubungan dengan gangguan pada mekanisme pengaturan tidur di otak. Namun, penting untuk diketahui bahwa ada banyak kondisi medis yang dapat mengganggu tidur nokturnal, sehingga mengakibatkan mengantuk di siang hari. Hal ini meningkat seiring dengan pertambahan usia. Tidur juga dapat terganggu pada stadium awal penyakit neurologis (contohnya, penyakit Parkinson dan Alzheimer). Kondisi ini dan keadaan potensial lainnya yang dapat menyebabkan gangguan tidur pada lanjut usia harus dieksklusi sebelum memikirkan perubahan intrinsik pada mekanisme sirkadian pengaturan tidur yang menjadi penyebabnya $(1,5)$.

\section{TINJAUAN PUSTAKA}

\section{Fisiologis Tidur}

Ada 2 status primer pada siklus tidur, yaitu REM (rapid eye movement) dan nonREM. Status nonREM dibagi menjadi 4 stadium, antara lain :

1. Stadium 1 : adalah saat transisi antara bangun dan tidur, durasi sekitar 30 detik sampai 7 menit dan ditandai oleh gelombang otak yang low-voltage pada pemeriksaan elektroensefalografi (EEG)

2. Stadium 2 : juga ditandai dengan gelombang otak low-voltage pada EEG, perbedaaanya dengan stadium 1 adalah adanya gelombang high voltage yang disebut "sleep spindles" dan $K$ complexes.

3. Stadium 3 dan 4 : sering disebut tidur yang dalam atau "delta sleep". EEG menunjukkan gelombang yang lambat dengan amplitudo yang tinggi (6).

REM ditandai dengan periode otonom yang bervariasi, seperti perubahan detak jantung, tekanan darah, laju pernapasan dan berkeringat. Pada stadium inilah mimpi saat tidur terjadi.Dua puluh lima persen waktu tidur dihabiskan pada status REM dan 75\% pada status nonREM (6).

Siklus tidur dan bangun (irama sirkadian) berfungsi mempertahankan untuk tetap terbangun saat siang hari saat cahaya terang dan tidur sepanjang malam hari saat gelap. Jadi faktor kuncinya adalah adanya perubahan gelap dan terang. Stimulasi cahaya terang akan masuk melalui mata dan 
mempengaruhi suatu bagian di hipotalamus yang disebut nukleus suprakiasmatikus (NSC). NSC akan mengeluarkan neurotransmiter yang mempengaruhi sekresi berbagai hormon pengatur temperatur badan, kortisol, GH (growth hormone) dan lain-lain yang memegang peran untuk bangun dan tidur. NSC bekerja seperti jam, meregulasi segala kegiatan bangun dan tidur. Jika pagi hari cahaya terang masuk, NSC segera mengeluarkan hormon yang menstimulasi peningkatan temperatur badan, kortisol dan GH sehingga orang terbangun. Jika malam tiba NSC merangsang pengeluaran hormon melatonin sehingga orang mengantuk dan tidur. Melatonin adalah hormon yang diproduksi oleh glandula pineal (suatu bagian kecil di otak tengah). Saat hari mulai gelap, melatonin dikeluarkan dalam darah dan akan mempengaruhi terjadinya relaksasi dan penurunan temperatur badan serta kortisol. Kadar melatonin dalam darah mulai meningkat pada jam 9 malam, terus meningkat sepanjang malam dan mencapai puncak pada saat kondisi tergelap (jam 03.00-05.00) dan menghilang pada jam 9 pagi (6).

Diketahui bahwa pada hari terjadi gangguan tidur, maka sebagai kompensasi dibutuhkan pengganti waktu tidur yang lebih lama (tekanan homeostasis tidur). Sistem homeostasis menentukan lama waktu tidur yang kita butuhkan, sedangkan sistem sirkadian mengoptimalkan waktu terbaik untuk tidur.

\section{Perubahan Pola Tidur pada Proses Penuaan}

Rekaman tidur polisomnografi (PSG) menunjukkan bahwa meskipun pada orang lanjut usia menghabiskan waktu lebih banyak di tempat tidur, mereka mengalami kesulitan untuk dapat tertidur, kurang tidur secara keseluruhan, lebih sering terbangun di malam hari, terbangun lebih awal di pagi hari sehingga mengurangi efisiensi tidur dan membutuhkan waktu tidur siang lebih banyak. Hasil dari Multiple Sleep Latency Tests (MSLTs), suatu pengukuran objektif untuk mengevaluasi rasa kantuk di siang hari melalui rekaman PSG saat tidur siang, menunjukkan bahwa secara signifikan orang lanjut usia lebih mengantuk sepanjang hari dibandingkan dengan orang dewasa muda (7). Gangguan tidur pada populasi lanjut usia dihubungkan dengan beberapa faktor, termasuk gangguan tidur spesifik, perubahan dari irama sirkadian endogen, kelainan medis dan psikiatri, serta pengaruh obat-obatan (8).

Pada orang lanjut usia, penurunan tekanan homeostasis tidur menurunkan jumlah gelombanglambat tidur. Selain itu, penurunan sinyal sirkadian pada lanjut usia menyebabkan penurunan suhu tubuh inti dan fase bangun dan waktu tidur. Terdapat bukti dari penelitian pada hewan coba dan studi pada manusia yang menyatakan amplitudo osilasi pada pacemaker sirkadian di nukleus suprakiasmatikus hipotalamus menurun selama proses penuaan. Proses penuaan mempengaruhi berbagai irama fisiologis yang mempengaruhi tidur, seperti suhu tubuh, sekresi melatonin, dan

fluktuasi sistem neuroendokrin (penurunan sekresi luteinizing hormone, growth hormone, dan thyroidstimulating hormone, rendahnya kadar serotonin) (1).

Dalam studi PSG, terdapat empat perubahan yang berhubungan dengan proses penuaan yang diobervasi: penurunan total waktu tidur, penurunan efisiensi tidur, penurunan tidur gelombang-lambat, dan peningkatan frekuensi terbangun setelah tidur. Suatu metaanalisis pada 3577 subyek pada usia 5 102 tahun menunjukkan perubahan arsitektur tidur dihubungkan dengan usia (Gambar 1). Pada grafik Gambar 1 menunjukkan pada orang dewasa, total waktu tidur, efisiensi tidur, persentase tidur gelombang-lambat, persentase tidur fase nonREM, dan fase REM semuanya mengalami penurunan seiring dengan pertambahan usia. Hal ini berbanding terbalik dengan WASO (wake after sleep onset) yang semakin meningkat seiring dengan pertambahan usia, hal ini menunjukkan bahwa pada lansia terjadi peningkatan frekuensi terbangun setelah tidur (9). 


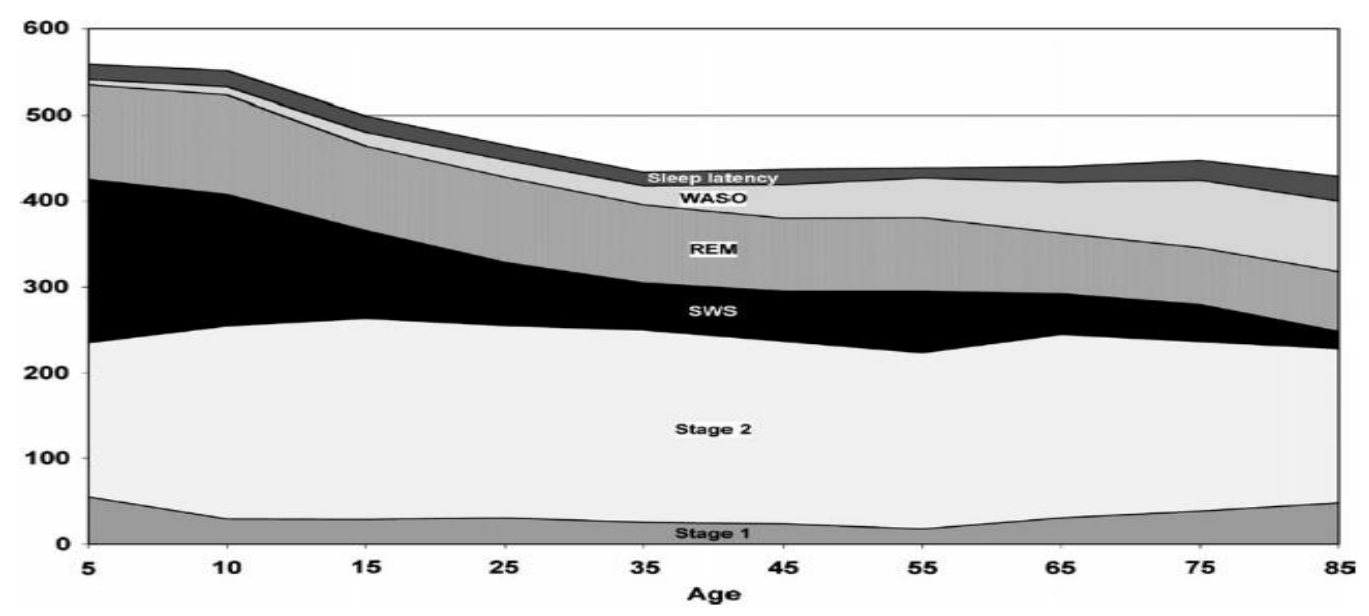

Gambar 1. Tren tidur terkait usia untuk tidur tahap 1 (stadium N1), tidur tahap 2 (stadium N2), slow-wave sleep (SWS), rapid eye movement (REM), wake after sleep onset (WASO), dan latensi tidur (dalam menit) (9).

\section{Tabel 1. Penyebab insomnia kronik pada orang lanjut usia (9)}

(1)Gangguan tidur primer

Sleep apnea syndrome

Restless legs syndrome, periodic limb movement disorder

Rapid eye movement sleep behavior disorder

Circadian rhythm sleep-wake disorders (advance and delayed sleep-wake phase disorder)

(2)Penyakit medis akut dan kronik

Alergi (rinitis alergi, hay fever); Nyeri (artritis, nyeri muskuloskeletal); Kardiovaskular (gagal jantung, sindroma koroner akut); Paru (pneumonia, chronic obstructive pulmonary disease); Metabolik (diabetes, penyakit tiroid), Gastrointestinal (gastroesophageal reflux disease, konstipasi/diare, kolitis akut, gastric ulcer); Kelainan miksi (nokturia, inkontinensia, overactive bladder, benign prostat hypertrophy pada laki - laki); Penyakit psikiatri (depresi, kecemasan, psikosis, delirium, alcoholism); Penyakit saraf (penyakit Alzheimer,penyakit Parkinson, penyakit serebrovaskular, epilepsi); Pruritus; Menopause

(3)Perilaku penyebab dan stress psikologis/fisik

Tidur siang; pergi ke tempat tidur lebih awal; menggunakan tempat tidur untuk aktivitas yang lain (menonton TV, membaca); kurangnya aktivitas fisik saat siang hari; meninggalnya pasangan hidup; kesendirian; rawat inap di rumah sakit

(4)Penyebab lingkungan

Bising, lampu, suhu dingin/panas, kelembapan, alas tidur yang kurang nyaman, kurangnya paparan cahaya selama siang hari

(5)Obat - obatan

Psikostimulan; antidepresan (selective serotonin reuptake inhibitors); antihipertensi (penyekat beta, penyekat alfa); obat - obatan antiparkinson (levodopa); bronkodilator (teofilin); steroid; antihistamin (Penyekat H1 dan H2); antikolinergik; alkohol; interferon

\section{Gangguan Tidur karena Gangguan Pernapasan (Sleep-Disordered Breathing)}


Sleep-disordered breathing (SDB) merupakan suatu gangguan respirasi, termasuk hipopneu (respirasi parsial) dan/atau apneu (henti napas total), selama tidur. Gangguan respirasi ini terjadi berulang sepanjang tidur malam dengan masing-masing gangguan respirasi terjadi minimal 10 detik. Jumlah apneu per jam saat tidur disebut dengan apnea index (AI) dan jumlah apneu dan hipopneu per jam saat tidur disebut dengan apnea-hypopnea index (AHI). Apneahypopnea index (AHI), yaitu menghitung jumlah total episode apneu dan hipopneu dibagi lama tidur. Jika AHI > 5 kali episode per jam maka diagnosis OSA dapat ditegakkan $(6,7,10,11)$.

Henti napas dalam SDB menyebabkan pasien terbangun berulang kali saat tidur, akibat penurunan kadar oksigen dalam darah sepanjang malam, yang menyebabkan hipoksemia malam hari (9). Berdasarkan hasil pemeriksaan polisomnografi, "The American Academy of Sleep Medicine" mengklasifikasikan OSA sebagai berikut:

1. OSA ringan : bila terdapat $5-15$ kali apneu per jam tidur

2. OSA sedang : bila terdapat $15-30$ kali apneu per jam tidur

3. OSA berat : bila terdapat $>30$ kali apneu per jam tidur

SDB lebih sering pada orang tua daripada dewasa muda. Pada populasi lanjut usia, SDB lebih sering terjadi pada laki-laki dibandingkan perempuan dan pada pasien hipertensi (7).

Gangguan tidur karena gangguan pernapasan sering disebut juga sleep apnea/hypopnea syndrome. Terdapat 3 tipe, yaitu : henti napas karena obstruksi (OSA) yaitu henti napas terjadi karena oklusi sebagian atau total saluran napas atas, henti napas karena proses sentral (central sleep apnea $=\mathrm{CSA}$ ) yaitu penurunan kemampuan atau tonus otot pernapasan karena gangguan rangsang bernapas dari pusat pernapasan di medula oblongata, dan tipe campuran keduanya $(4,5)$.

Gangguan tidur karena gangguan pernapasan (GTGP), merupakan interaksi kompleks dari sistem saraf pusat dan perifer, otot-otot saluran napas atas dan beberapa neurotransmiter yang menyebabkan kolaps sebagian atau seluruh hulu kerongkongan (faring), sehingga mengakibatkan obstruksi jalan napas dan hipoksia (6).

Gejala utama SDB adalah mendengkur dan mengalami rasa kantuk yang berlebihan saat siang hari. Saat tidur pada penderita GTGP terdapat : mengorok sangat keras, tersedak dan batuk-batuk, henti napas beberapa detik, terdapat gerakan-gerakan seperti orang kehabisan napas. Gejala lainnya ialah insomnia, nocturnal confusion, dan defisit kognitif seperti gangguan konsentrasi dan memori. Peningkatan SDB dihubungkan dengan peningkatan risiko terjadinya penyakit kardiovaskuler, termasuk hipertensi, penyakit arteri koroner, dan stroke $(6,7,12)$.

\section{Manajemen}

Terapi konservatif pada OSAyaitu: posisi tidur miring, terapi hidung tersumbat, hentikan pemakaian alkohol dan obat-obat sedatif serta penurunan berat badan. Episode apneu/hipopneu lebih banyak terjadi saat tidur telentang dan setelah pemakaian obat benzodiazepine atau setelah minum alkohol. Penurunan berat badan 10\% dapat menurunkan 26\%episode apneu per jam. Terapi OSA ditujukan untuk menyembuhkan penyakit yang mendasarinya, pemberian oksigen dapat membantu meringankan gejala apneu, tetapi kadang diperlukan bantuan ventilator bertekanan positif yang diberikan intermiten bila terdapat tanda-tanda hipoksia (6). Terapi farmakologis SDB tidak efektif. Terdapat beberapa terapi nonfarmakologi yang efektif, dianggap sebagai lini pertama pengobatan pada SDB (7). 


\section{Positive Airway Pressure}

Standar baku terapi pada SDB adalah dengan pemberian tekanan positif pada saluran napas. Ada beberapa jenis perangkat yang memberikan tekanan udara positif, termasuk continuous positive airway pressure (CPAP), bilevel positive airway pressure (BiPAP), dan auto-CPAP. CPAP terdiri dari masker hidung, yang dihubungkan melalui selang ke mesin yang memberikan tekanan udara terus menerus. Tekanan udara berperan mempertahankan agar jalan napas bagian atas tetap terbuka, sehingga mencegah obstruksi atau kolapsnya saluran napas. Tingkat tekanan udara $\left(5-20 \mathrm{cmH}_{2} \mathrm{O}\right)$ diatur per individu untuk setiap pasien di laboratorium tidur dan tergantung dari nilai AHI pasien atau derajat keparahan SDB pasien. Indikasi pemakaian CPAP adalah OSA berat tanpa gejala, OSA ringan sampai sedang dengan gejala mengantuk berat pada siang hari, penurunan kognitif dan adanya penyakit kardiovaskular (hipertensi, penyakit jantung iskemik dan stroke) $(6,7)$.

\section{Terapi pembedahan}

Prosedur bedah yang biasa dilakukan untuk OSA adalah pembedahan untuk menghilangkan hidung tersumbat seperti deviasi septum, adenoidektomi, uvulopalatopharingoplasty (UPPP), laser-assisted uvulopalatoplasty (LAUP), tonsilektomi, reseksi sebagian atau ablasi lidah, dan rekonstruksi mandibula atau maksila. Indikasi terapi bedah adalah penderita dengan OSA berat simtomatik atau bila penanganan konservatif dan pemakaian alat CPAP dan atau alat mulut tidak berhasil memperbaiki gangguan tidur karena gangguan pernapasan (GTGP) $(6,7,13)$.

\section{Terapi dengan alat-alat mulut (oral aplliance)}

Alat oral aplliancedirekomendasikan untuk penderita OSA ringan dan sedang yang tidak dapat mentoleransi penggunaan CPAP. Alat ini biasa dipasang pada gigi saat tidur untuk mereposisi bentuk mandibula, memodifikasi palatum posterior dan bagian belakang lidah. Hanya efektif untuk beberapa penderita GTGP yang memiliki kelainan anatomi faring. Dua alat yang sering digunakan ialah tongue-retaining device (TRD) dan mandibular advancement device (MAD) $(6,7)$.

\section{Diet dan perubahan pola hidup}

Ada beberapa diet dan pola hidup yang dapat memperburuk SDB, seperti obesitas, konsumsi alkohol, dan merokok. Obesitas merupakan penyebab tersering obstructive sleep apnea, sebagai akibat penumpukan jaringan lemak di sekitar saluran napas sehingga menyebabkan obstruksi jalan napas bagian atas. Dengan penurunan berat badan dapat membantu mengurangi atau bahkan menghilangkan periode apneu. Alkohol dan beberapa obat, seperti hipnotik-sedatif, narkotika, dan barbiturat, memiliki efek depresi pada otot saluran napas atas dan dapat memperburuk SDB. Oleh karena itu, klinisi harus mempertimbangkan dengan baik saat meresepkan obat-obat sedasi, terutama pada pasien lanjut usia yang memiliki risiko tinggi SDB. Merokok dapat memperburuk SDB, melalui iritasi pada orofaring oleh asap rokok dan efek dari nikotin pada sistem saraf pusat. SDB karena posisi dapat juga terjadi pada posisi tidur terlentang, akibat relaksasi dari otot leher anterior dan struktur orofaringeal (7).

Secara umum, terapi SDB pada pasien lanjut usia bergantung dari (1) derajat keparahan, (2) beratnya gejala di siang hari, (3) adanya kondisi komorbid, seperti hipertensi, penyakit jantung, atau defisit kognitif (7). 


\section{Gangguan Gerakan Tungkai yang Periodik (Periodic Limb Movements in Sleep) atauSindrom Kaki Kurang Tenang (Restless Legs Syndrome)}

Periodic limb movement in sleep (PLMS) ditandai dengan sekelompok gerakan sentakan kaki berulang (terkadang lengan) yang terjadi setiap 20 - 40 detik sekali sepanjang malam. Kelompok gerakan ini bertahan rata-rata 0,5 - 5 detik dan menyebabkan pasien berulang kali terbangun singkat. Jumlah gerakan anggota badan yang diikuti oleh keadaan terbangun per jam disebut dengan periodic limb movement index (PLMI). Diagnosis klinis PLMS bila pasien memiliki PLMI > $5(7,14)$.

Gangguan lainnya yang sering komorbid dengan PLMS, dan dianggap lebih mengganggu, ialah restless leg syndrome (RLS). RLS ditandai dengan rasa tidak nyaman yang berlebihan terutama pada kaki selama malam hari saat penderita istirahat. Sindrom ini adalah bentuk dari akathisia, sering disebut sebagai perasaan seperti dirayapi semut atau hewan kecil. Perasaan ini menyebabkan pasien mengerakkan kakinya atau bangun lagi untuk berjalan berkeliling guna menghilangkan rasa tidak nyaman ini. Sensasi ini sering terjadi pada malam hari atau kapanpun saat pasien berada dalam keadaan santai atau istirahat. Sekitar $90 \%$ pasien RLS juga memiliki PLMS, namun hanya sekitar 20\% pasien PLMS yang menderita RLS $(6,7,10,14)$.

Prevalensi PLMS dan RLS meningkat secara signifikan seiring dengan pertambahan usia. Tidak ada perbedaan jenis kelamin dalam prevalensi PLMS, namun pada RLS dua kali lebih sering terjadi pada wanita usia tua dibandingkan dengan laki-laki (7).

Mekanisme pasti yang mendasari PLMS dan RLS belum sepenuhnya dipahami. Hipotesis terbaru menyatakan kemungkinan disfungsi pada sistem dopamin. Teori ini berasal dari efek terapeutik dari agonis dopamin pada RLS dan PLMS. Studi terakhir menunjukkan bahwa patofisiologi dari RLS mungkin melibatkan disregulasi homeostasis besi, kadar feritin di cairan serebrospinal lebih rendah pada pasien ini (7).

Keluhan paling umum dari pasien PLMS adalah gangguan inisiasi tidur, gangguan mempertahankan tidur, dan rasa kantuk yang berlebihan di siang hari. Gerakan-gerakan ini sebagian besar tidak membangunkan pasien meskipun pasien melakukan 100 kali tendangan semalam. Hanya tendangan dengan frekuensi dan intensitas tinggi yang dapat membangunkan pasien. Pasien mungkin tidak menyadari mengenai tendangan atau sentakan kaki ini. Biasanya pasangan tidur yang menyadari gerakan kaki ini dan pindah ke tempat tidur yang terpisah. Pasien sering mengeluhkan rasa lelah yang berlebihan saat bangun tidur dan tidak nyenyak tidur. Banyak pasien PLMS juga menderita RLS sehingga mengeluh sensasi tidak nyaman di kaki saat siang hari (7).

\section{Manajemen}

Terapi PLMS dan RLS sama. Terapi konservatif dengan merendam kaki dan tungkai atas dengan air hangat serta olahraga ringan (jalan kaki) yang dikerjakan teratur dapat membantu menghilangkan gejala kedua gangguan tidur ini. Terapi lini pertama untuk PLMS/RLS terdiri dari agonis dopamin, karena dapat mengurangi atau mengeliminasi baik sentakan pada anggota tubuh dan akibatnya. Ada 2 pengobatan yang disetujui Food and Drug Administration (FDA) untuk RLS: ropinirole dan pramipexole. Carbidopa/levodopa juga efektif $(7,14)$. 
Tabel 2. Terapi farmakologis PLMS/RLS (7)

\begin{tabular}{llll}
\hline GOLON & GENERI & MER & DOSIS \\
GAN & K & EK & \\
OBAT & & OBA & \\
& & T & \\
\hline Obat - & Ropinirol & Requi & $1,5-4 \mathrm{mg}$ \\
obatan & e & p & $0,25-0,75$ \\
dopamine & Pramipex & Mirap & mg \\
rgik & ole & ex & $25 / 100-$ \\
& Carbidop & Sine & $25 / 250 \mathrm{mg}$ \\
& a/ & met & \\
& Levodop & & \\
& a* & & \\
\hline Benzodia & Clonazep & Klon & $0,25-2 \mathrm{mg}$ \\
zepin & am & opin & $15-30 \mathrm{mg}$ \\
& Tempaze & $\begin{array}{l}\text { Resto } \\
\text { ril }\end{array}$ \\
& pam & \\
\hline Golongan & Kodein & Tylen & $30-60 \mathrm{mg}$ \\
opiate & Propoxyp & ol & (kodein) \\
& hene & Darv & $65-135 \mathrm{mg}$ \\
& hydrochl & on & \\
& oride & & \\
\hline *off-label & & & \\
\hline
\end{tabular}

\section{Circadian Rhythms Sleep Disorders}

Irama sirkadian mengacu pada ritme biologis 24 jam yang mengendalikan banyak fungsi fisiologis, seperti sekresi hormon endogen, suhu tubuh inti, dan siklus tidur-bangun. Irama ini berasal dari nukleus suprakiasmatikus $(\mathrm{SCN})$ di hipotalamus anterior, yang merupakan tempat pacemaker sirkadian internal. Irama sirkadian disinkronisasi ke 24 jam sehari oleh ritme internal lainnya (misalnya sekresi hormon), dan juga oleh zeitgebers eksternal. Siklus tidur-bangun terutama dipengaruhi oleh irama internal, seperti suhu tubuh inti, siklus melatonin endogen, dan irama terang/gelap eksternal, yang mempengaruhi pada siklus tidur-bangun melalui jalur visual retinohipotalamus. Sebagai contoh, saat suhu tubuh inti menurun, sekresi melatonin meningkat dan individu mulai mengantuk, namun saat suhu tubuh inti meningkat dan sekresi melatonin menurun, individu mulai terbangun (7).

Seiring bertambahnya usia, beberapa faktor dapat mempengaruhi irama sirkadian sehingga menyebabkan irama tidur-bangun menjadi tidak teratur. Perubahan tersebut meliputi (1) degenerasi lambat dari SCN seiring pertambahan usia, (2) penurunan progresif sekresi melatonin endogen sepanjang malam, dan (3) penurunan sensitivitas terhadap faktor eksternal, seperti penurunan kepekaan terhadap cahaya terang pada orang lanjut usia (7).

Perubahan lain dari irama sirkadian yang sering pada pasien lanjut usia ialah siklus tidur bangun yang bergeser atau maju. Gangguan irama sirkadian ini disebut dengan advanced sleep phase syndrome (ASPS), suatu kondisi siklus tidur-bangun dan siklus suhu tubuh inti berubah, dibanding dengan orang dewasa yang lebih muda. Orang dewasa yang lebih tua dengan ASPS 
mengantuk di sore hari dan terbangun saat dini hari, sebagian karenasuhu tubuh inti menurun terlalu awal di malam hari (sekitar pukul 19.00 atau 20.00) dan meningkat 8 jam kemudian, sekitar pukul 03.00 atau 04.00 (7).

Prevalensi ASPS sekitar 1\% pada orang dewasa setengah baya. Meski prevalensi pada orang lanjut usia diketahui meningkat, namun persentase pasti masih belum ditetapkan (7).

Perubahan pada siklus tidur-bangun disebabkan karena perubahan dari siklus suhu tubuh inti, penurunan paparan cahaya, dan faktor lingkungan. Penelitian terakhir menunjukkan kemungkinan ada keterkaitan dengan faktor genetik (7).

Keluhan tersering pada pasien ASPS adalah mudah mengantuk di sore hari dan terbangun terlalu dini di pagi hari (7).

\section{Manajemen}

Perubahan irama sirkadian merupakan hal yang umum dan sering terjadi pada orang lanjut usia, oleh karena itu pasien harus mendapatkan edukasi yang adekuat bahwa ASPS bukan merupakan suatu kelainan medis dan tidak membutuhkan obat-obatan. Terapi non-farmakologis berfokus pada penguatan dari siklus tidur-bangun, merupakan terapi pilihan pada pasien ASPS, terutama terapi cahaya terang (7).

\section{Terapi cahaya terang}

Cahaya terang merupakan faktor zeitgeber eksternal yang paling mempengaruhi siklus tidur-bangun, sehingga ini merupakan terapi yang paling tepat dan efektif untuk gangguan irama sirkadian. Dengan meningkatkan paparan cahaya pada waktu tertentu, memungkinkan untuk menunda siklus tidur-bangun. Paparan terhadap cahaya terang di pagi hari akan memperkuat dan meningkatkan irama sirkadian (pasien akan mengantuk lebih cepat), namun saat paparan cahaya terang diberikan siang menjelang sore hari atau di awal sore hari akan menunda irama (pasien akan mengantuk belakangan sehingga lebih lama terjaga). Paparan terhadap cahaya terang tidak hanya akan menggeser siklus tidur-bangun tapi juga mempengaruhi irama suhu tubuh inti dan melatonin endogen. Untuk menunda siklus tidur-bangun, pasien ASPS harus terpapar dengan cahaya terang sekitar 2 jam sehari saat siang menjelang sore hari. Sumber cahaya terang terbaik adalah sinar matahari, sehingga dianjurkan pasien menghabiskan waktu di luar rumah saat siang menjelang sore hari tersebut. Pencahayaan dalam ruangan tidak cukup terang untuk dapat menggeser irama sirkadian. Bila pasien tidak dapat menghabiskan waktu di luar rumah selama 2 jam, alternatif lain ialah dengan mengunakan "light box", yang menyediakan minimal 2500 luks cahaya (7).

\section{Rapid Eye Movement Sleep Behavior Disorder}

Rapid eye movement (REM) kelainan sikap tidur (RBD) ditandai dengan terjadinya perilaku motorik kompleks, sebagian besar akibat atonia otot rangka intermiten sepanjang fase tidur REM. Proses yang mendasari gangguan ini adalah adanya disinhibisi transmisi aktivitas motorik saat bermimpi. RBD biasanya terjadi pada separuh kedua malam, lebih sering saat fase REM. Perilaku pada RBD termasuk gerakan tubuh kompleks yang kuat seperti berjalan, berbicara dan makan $(6,7)$. 
Prevalensi RBD masih belum diketahui. Laporan terakhir menunjukkan bahwa laki-laki lanjut usia memiliki risiko lebih tingi untuk terjadinya RBD (7).

Etiologi RBD masih belum diketahui. Beberapa penelitian menunjukkan bahwa RBD akut berhubungan dengan konsumsi antidepresan trisiklik, fluoxetine, monoamine oxidase inhibitor, dan akibat penghentian dari konsumsi alkohol atau sedatif. Hal ini berbeda dengan RBD kronik, yang dikaitkan dengan narkolepsi dan gangguan neurodegeneratif idiopatik lainnya seperti demensia dan penyakit Parkinson (7).

Pasien melakukan perilaku motorik kompleks sepanjang malam dan tidak mampu mengingat tindakan tersebut di pagi hari. Beberapa pasien mengingat gerakan yang dilakukan merupakan bagian dari mimpi, mungkin disebabkan karena kurangnya atonia otot saat fase REM. Gerakan yang terjadi dapat membahayakan pasien dan/atau pasangan tidur. Pasien sering jatuh atau melompat dari tempat tidur sehingga terjadi cedera $(6,7)$.

\section{Manajemen}

\section{Intervensi Farmakologis}

Klonazepam merupakan terapi farmakologis tersering untuk RBD. Klonazepam bekerja dengan menghambat gerakan motorik di malam hari, tanpa mempengaruhi tonus otot secara langsung. Pengobatan ini menunjukkan penghentian (sebagian atau seluruhnya) dari gerakan tubuh abnormal sepanjang malam pada $90 \%$ pasien RBD. Bila pengobatan dihentikan, semua gejala kembali. Beberapa alternatif obat yang memiliki efek positif pada RBD, termasuk antidepresan trisiklik, agen dopaminergik, dan melatonin (7).

\section{Pola hidup}

Klinisi harus memberikan edukasi kepada pasien RBD dan pasangan tidurnya untuk mengubah rutinitas tidur atau lingkungan tidur, dengan tujuan membuat kamar tidur lebih aman dan mengurangi risiko cedera saat malam hari. Sebagai contoh, harus terpasang gorden berat pada jendela kamar tidur, pintu dan jendela harus terkunci saat malam, jika ada risiko pasien berjalan keluar dari tempat tidur pada malam hari dan melakukan perilaku kompleks. Bila pasien sangat aktif, benda pecah belah atau benda berat harus disingkirkan dari sekitar tempat tidur, dan bila diperlukan pasien tidur di kasur yang diletakkan di atas lantai untuk mencegah terjatuh dari tempat tidur dan/atau menyakiti diri sendiri atau pasangan tidurnya (7).

\section{Insomnia}

Menurut International Classification of Sleep Disorders, Edisi Ketiga, insomnia adalah suatu keluhan subjektif terhadap kesulitan untuk memulai tidur, kesulitan untuk mempertahankan tidur, atau terbangun dini hari yang terjadi minimal 3 malam dalam seminggu, selama 3 bulan, dan mempengaruhi keadaan siang hari secara signifikan. Sebagai contoh akibatnya di siang hari termasuk kesulitan untuk berkonsentrasi, gangguan mood, lemah, dan cemas mengenai tidur (15).

Prevalensi insomnia lebih besar pada orang lanjut usia daripada usia dewasa muda, dengan prevalensi $40 \%-50 \%$ untuk insomnia gangguan mempertahankan tidur, dan insidens sekitar 5\%. Dilaporkan lebih banyak terjadi pada perempuan dibanding dengan laki-laki (7). 
Insomnia paling sering komorbid dengan kelainan medis, psikiatri, atau kondisi psikososial, dan/atau sekunder dari pengobatan insomnia sendiri. Penyakit yang sering pada orang lanjut usia, seperti arthritis, penyakit kardiovaskuler, penyakit paru, nyeri kronik, dan lainnya dihubungkan dengan rasa tidak nyaman, dan sering berhubungan dengan insomnia. Perubahan hidup mayor seperti pensiun dan kehilangan orang tercinta, dapat menyebabkan insomnia. Depresi dan rasa cemas merupakan kondisi komorbid yang berhubungan dengan gangguan tidur pada orang lanjut usia. Hanya sekitar 7\% dari insidens insomnia pada lanjut usia yang tidak berhubungan dengan kondisi-kondisi tersebut (7).

Pengobatan farmakologis seperti pada Tabel 3, sering menyebabkan gangguan tidur, sebagai contoh obat stimulan yang terlambat diminum menyebabkan kesulitan untuk tertidur di malam hari. Selain itu, obat-obatan sedasi yang diminum terlalu dini di pagi hari mengakibatkan rasa kantuk yang berlebihan di siang hari sehingga pasien tidur siang lama, dan menyebabkan insomnia malam harinya (7).

Tabel 3. Pengaruh beberapa obat yang dikonsumsi orangtua (7)

\begin{tabular}{ll}
\hline SEDASI & OBAT - OBATAN STIMULAN \\
\hline Hipnotik & Alkohol/nikotin \\
Antihipertensi & Stimulan CNS \\
Antihistamin & Hormon tiroid \\
Antipsikotik & Bronkodilator \\
Antidepresan & Kortikosteroid \\
& Penyekat beta \\
& Kalsium antagonis \\
\hline
\end{tabular}

Keluhan insomnia sangat bervariasi pada setiap individu, mulai dari gangguan tidur pada berbagai periode tidur (awal, pertengahan, atau akhir), pasien sering mengeluh mengalami rasa kantuk yang berlebihan di siang hari dan menurunkan fungsi mental (7).

\section{Manajemen}

Ada beberapa terapi perilaku, farmakologis dan perubahan gaya hidup dalam manajemen insomnia. Klinisi harus memulai terapi perilaku sebelum memberikan terapi farmakologis (7).

\section{Terapi Non-farmakologis}

Terapi non-farmakologis sangat efektif mengurangi insomnia termasuk cognitivebehavioral treatments (CBT) dan edukasi. Berikut adalah beberapa intervensi non-farmakologis yang umum digunakan (7).

\section{Sleep Hygiene}


Sleep Hygiene merupakan daftar panduan untuk dapat mempertahankan rutinitas tidurbangun yang sehat. Tabel 4 menunjukkan aturan sleep hygiene yang sudah diadaptasi untuk orang tua (7).

Tabel 4. Aturan sleep hygiene untuk orangtua (7)

\begin{tabular}{l}
\hline Periksa pengaruh obat - obatan pada tidur dan saat terjaga \\
\hline Hindari kafein, alkohol, dan rokok setelah makan siang \\
\hline Batasi cairan saat malam hari \\
\hline Pertahankan jadwal waktu tidur-waktu bangun secara teratur \\
\hline Hindari tidur siang atau batasi waktu tidur siang tidak melebihi 30 menit \\
\hline Habiskan waktu diluar rumah (tanpa kacamata hitam), terutama pada saat \\
akhir sore hari atau awal sore hari \\
\hline Latihan fisik
\end{tabular}

\section{Stimulus-Control Therapy}

Pasien harus menghindari aktivitas sebelum waktu tidur, seperti menonton televisi ataumembaca buku. Kebiasaan tidur siang harus dicegah, sehingga kebutuhan tidur akan terakumulasi. Pada pasien lanjut usia bila sangat diperlukan, dapat tidur siang namun tidak lebih dari 30 menit. Ada beberapa aturan yang dapat diikuti untuk mengatasi insomnia, yang dapat dilihat pada Tabel $5(7,16)$.

\section{Tabel 5. Instruksi Terapi Kontrol Stimulus untuk orangtua (7)}

1. Pasien seharusnya pergi tidur hanya jika merasa lelah atau mengantuk

2. Jika tidak bisa tertidur dalam waktu 20 menit, pasien harus bangun dari tempat tidur (bila memungkinkan keluar dari kamar tidur). Ketika di luar kamar tidur, melakukan aktivitas yang tenang dan santai.

3. Pasien harus kembali ke tempat tidur jika merasa mengantuk

4. Jika tidak bisa tertidur kembali dalam waktu 20 menit, pasien harus bangun dari tempat tidur kembali

5. Tindakan tersebut diulang kembali sampai pasien dapat tertidur dalam beberapa menit

6. Pasien harus bangun dengan waktu yang sama saat pagi hari (meskipun tidur hanya dalam beberapa jam saja)

7. Tidur siang harus dihindari

\section{Sleep-Restriction Therapy}

Tabel 6 menunjukkan ringkasan instruksi untuk sleep-restriction therapy.

Tabel 6. Instruksi Sleep Restriction Therapy untuk orang tua (7)

1. Hitung rata - rata jumlah waktu tidur tiap malam yang disampaikan oleh pasien

2. Pasien hanya diperbolehkan untuk tetap di tempat tidur dengan waktu tambahan 15 menit 
3. Pasien harus bangun pada waktu yang sama setiap hari

4. Tidur siang harus benar - benar dihindari

5. Ketika efisiensi waktu tidur mencapai $80 \%$ sampai $85 \%$, pasien dapat pergi ke tempat tidur 15 menit lebih awal

6. Langkah - langkah ini harus diulangi sampai pasien dapat tidur selama 8 jam (atau mencapai waktu tidur yang diperlukan untuk mencapai kualitas tidur malam yang baik)

\section{Cognitive-Behavioral Therapy (CBT)}

CBT pada insomnia meliputi edukasi, komponen perilaku, dan kognitif. Komponen edukasi melibatkan pasien untuk menentukan faktor apa yang mungkin menjadi predisposisi, pencetus, atau yang mempertahankan insomnia. Terapis menjelaskan bahwa CBT efektif dengan mengurangi faktor-faktor penyebab insomnia dengan pendekatan perubahan perilaku dan kognitif. Komponen perilaku melibatkan teknik perilaku seperti yang sudah dijelaskan sebelumnya. Komponen kognitif berhubungan dengan pikiran maladaptif dan keyakinan disfungsional yang dimiliki pasien tentang insomnia (7).

\section{Terapi Farmakologis}

Bila pengobatan hipnotik dibutuhkan untuk pasien lanjut usia, klinisi harus mempertimbangkan beberapa hal berikut: (1) meresepkan dimulai dengan dosis terendah yang efektif, (2) mengunakan hipnotik dengan waktu paruh singkat, dan (3) evaluasi kemungkinan efek samping yang muncul pada SDB dan performa di siang hari. Secara umum, hipnotik kerja panjang merupakan kontraindikasi pada pasien lanjut usia. Terapi farmakologis insomnia dapat dilihat pada Tabel $7(7,17)$.

\begin{tabular}{|c|c|c|c|c|}
\hline GENERIK & MEREK & DOSIS (mg) & JENIS INSOMNIA & $\begin{array}{l}\text { WAKTU } \\
\text { PARUH (jam) }\end{array}$ \\
\hline Zaleplon & Sonata & $5-20$ & Onset-tidur & 1 \\
\hline Zolpidem & Ambien & $5-10$ & Onset-tidur & $2,5-3$ \\
\hline Zolpidem MR & Ambien CR & $6,25-12,5$ & $\begin{array}{l}\text { Onset-tidur dan } \\
\text { durasi tidur }\end{array}$ & 2,8 \\
\hline Eszopicolone & Lunesta & $1-3$ & $\begin{array}{l}\text { Onset-tidur dan } \\
\text { durasi tidur }\end{array}$ & 6 \\
\hline Remelteon & Rozerem & 8 & Onset-tidur & $1-2,6$ \\
\hline
\end{tabular}

Tabel 7. Obat Nonbenzodiazepin yang disetujui FDA untuk Terapi Insomnia (7)

\section{Kondisi Khusus}

Gangguan tidur pada pasien lanjut usia yang dirawat di Panti Jompo dan dengan gangguan neurodegeneratif 
Tidur pada pasien lanjut usia yang tinggal di Panti Jompo biasanya mengalami gangguan, terutama pada mereka yang mengalami kelainan neurodegeneratif seperti penyakit Alzheimer, Parkinson, Huntington, dan bentuk lain dari demensia. Pasien dengan demensia lebih rentan mengalami kerusakan permanen pada daerah otak yang mengatur tidur. Penyebab tersering gangguan tidur pada pasien lanjut usia di Panti Jompo adalah sering terbangun di malam hari (7).

Pada penyakit Alzheimer, pasien mengalami peningkatan yang progresif dari lama dan frekuensi terbangun di malam hari, peningkatan tidur di siang hari, dan penurunan tidur gelombang-lambat dan fase REM dibandingkan dengan orang lanjut usia yang sehat. Pasien yang dirawat di Panti Jompo sering mengalami tidur yang terfragmentasi $(7,18)$.

Faktor lingkungan di Panti Jompo dapat berperan terhadap penurunan kualitas tidur. Di Panti Jompo, paparan suara dan cahaya yang terjadi berulang sepanjang malam dapat mengakibatkan gangguan tidur pada pasien. Tabel 8 menunjukkan beberapa strategi sleep hygiene pada pasien yang dirawat di Panti Jompo $(7,19)$.

\section{Tabel 8. Strategi sleep hygiene pada pasien di Panti Jompo (7)}

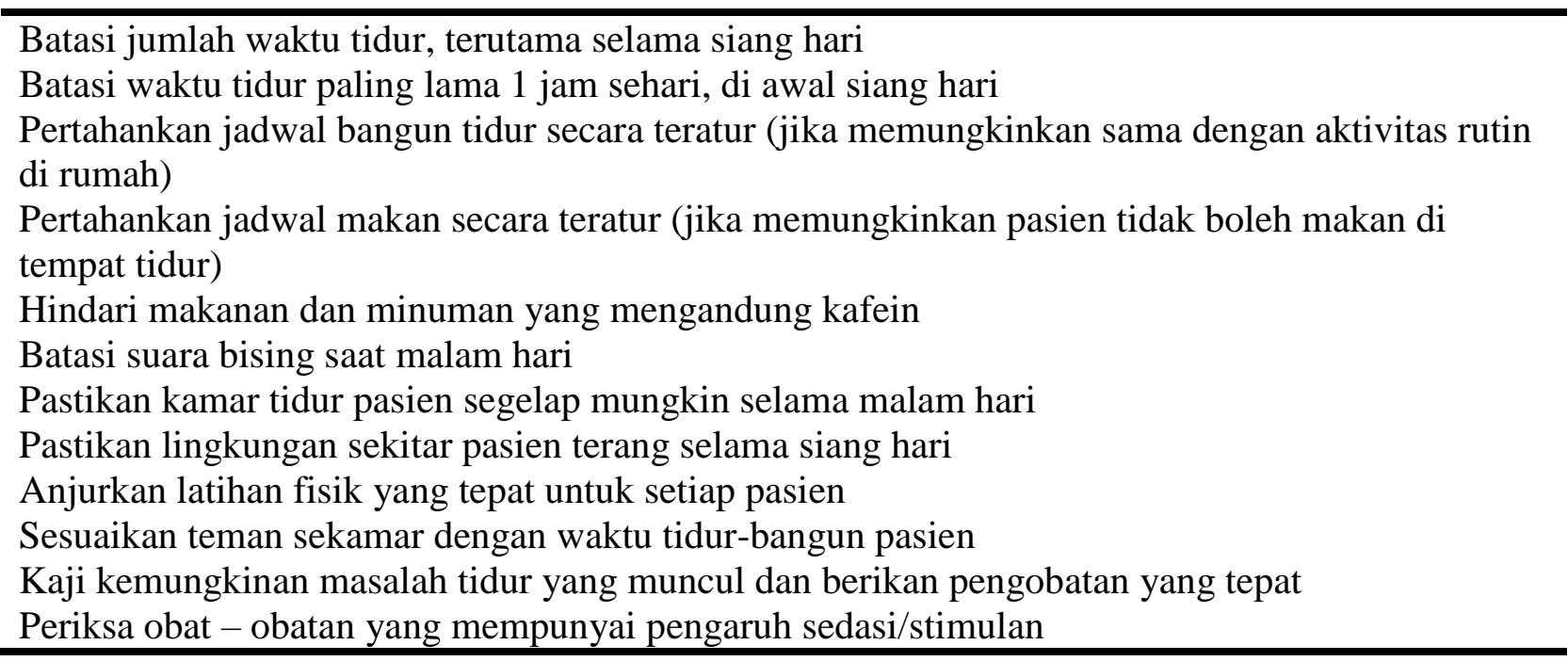

\section{KESIMPULAN}

Tidur yang adekuat merupakan komponen inti untuk mempertahankan kesehatan fisik dan mental yang baik serta menurunkan risiko penyakit. Terapi untuk gangguan tidur meliputi terapi non-farmakologis dan terapi farmakologis. Terapi non-farmakalologis merupakan terapi lini pertama yang direkomendasikan sebagai pengobatan gangguan tidur pada pasien lanjut usia. Bila membutuhkan terapi farmakologis maka pilihannya adalah obat dengan waktu paruh yang pendek dan dimulai dengan dosis terendah yang efektif. 


\section{DAFTAR PUSTAKA}

1. Sterniczuk R., Rusak B. Sleep in Relation to Aging, Frailty, and Cognition. In: Fillit HM., Rockwood K., Young J (ed). Brocklehurst's Textbook of Geriatric Medicine and Gerontology. Eight Edition. Philadelphia: churchill Livingstone Elsevier Science. 2017; p. $908-913$.

2. Hellstrom A., Hellstrom P., Willman A., Fagerstrom C. Association between Sleep Disturbances and Leisure Activities in the Elderly: A Comparison between Men and Women. Hindawi. 2013: 1-11.

3. Gambhir IS., Chakrabarti SS., Sharma AR., Saran DP. Insomnia in the Elderly A hospitalbased study from North India. Journal of Clinical Gerontology \& Geriatrics. 2014; 5: 117121.

4. Coll PP. Sleep disorders. In: Adelman AM., Daly MP., Weiss BD (ed). 20 Common Problems in Geriatrics. Boston: McGraw-Hill Companies. 2001; p. 187 - 203.

5. Foley D., Ancoli S., Britz P. Sleep Disturbances and Chronic Disease in Older Adults: Result of 2003 National Sleep Foundation Sleep in America Survey. J Psychosom Res. 2004; 58: 497-502.

6. Rahayu RA.. Gangguan Tidur pada Usia Lanjut. In: Setiati S., Alwi I., Sudoyo AW., Simadibrata M., Setiyohadi B., Syam AF. (ed). Buku Ajar Ilmu Penyakit Dalam Edisi VI. Jakarta: Interna Publishing. 2014; p. 3823 - 3833.

7. Cohen M., Ancoli S. Sleep Disorders. In: Halter JB., Ouslander JG., Tinetti ME., Studenski S., High KP., Asthana S (ed). Hazzard's Geriatric Medicine and Gerontology. Sixth Edition. United States: The McGraw-Hill Companies. 2009; p. 700 - 710.

8. Feldman S., Abernathy J. Management of Sleep Disoders in the Elderly. The American Society of Consultant Pharmacists. 2000; 15(2): 1-13.

9. Suzuki K., Miyamoto M., Hirata K. Sleep Disorders in the Eldery: Diagnosis and Management. Journal of General and Family Medicine. 2017; 18:61-71.

10. Martin JL., Alam T., Alessi CA. Sleep Disorders. In: Ham RJ., Sloane PD., Warshaw GA., Bernard MA., Flaherty E (ed). Primary Care Geriatrics. A Case Based Approach. Fifth Edition. Philadelphia: Mosby Elsevier. 2007; p. 391 - 400.

11. Lam J., Lam B. Sleep Apnoea/Hypopnoea Syndrome. Medical Progress. 2004; 31: 543-548.

12. Quan SF., Katz R., Olson J. Factors Associated with Incidence and Persistence of Symptoms of Disturbed Sleep in Elderly Cohort: The Cardiovascular Health Study. Am J Med Sci. 2005; 329:163-172.

13. Wei WI., Ho WK. Surgery for Snoring. Medical Progress. 2004; 31: 538-542.

14. Montgomery P. Sleep Disorders in Eldery People. In: Pathy MSJ., Sinclair AJ., Morley JE (ed). Principles and Practice of Geriatric Medicine. Fourth Edition. Vol 2. Oxford: John Wiley \& Sons. 2006; p. 733 - 740.

15. Rodriguez JC., Dzierzewski JM., Alessi CA. Sleep Problems in the Elderly. Med Clin North Am. 2015; 99(2): 431-439.

16. Ancoli S., Ayaloon L. Diagnosis and treatment of sleep disorders in older adults. Winner. 2009; 7(1): 98-105.

17. Lenzer J. FDA Warns about Using Antipsychotic Drugs for Dementia. BMJ. 2005: 330-922.

18. Alessi CA., Schnelle JF. Approach to Sleep Disorders in the Nursing Home Setting. Sleep Med Rev. 2000; 4: 45-56.

19. Cooke JR., Ancoli S. Normal and Abnormal Sleep in the Elderly. Handb Clin Neurol. 2011; 98: 653-665. 